\title{
Тетяна Близнюк,
} кандидат педагогічних наук, доцент кафедри педагогіки початкової освіти, ДВНЗ «Прикарпатський національний університет імені Василя Стефаника»

\section{Tetyana Blyznyuk,}

$\mathrm{PhD}$ in Education, Associate Professor Department of Pedagogy of Primary Education, Vasyl Stefanyk Precarpathian National University (Ivano-Frankivsk, Ukraine)

blyztan@yahoo.com

ORCID ID 0000-0002-0558-2201

\section{Ольга Троценко,}

кандидат педагогічних наук, доцент кафедри англійської філології факультету іноземних мов, ДВНЗ "Прикарпатський національний університет імені Василя Стефаника" (м.Івано-Франківськ, Україна)

\author{
Olga Trotsenko, \\ $\mathrm{PhD}$ in Education, \\ Associate Professor \\ English Philology Department of the Faculty of Foreign \\ Languages \\ Vasyl Stefanyk Precarpathian National University \\ (Ivano-Frankivsk, Ukraine) \\ trocolya@gmail.com \\ ORCID ID 0000-0002-5023-0563
}

УДК 37.013.78: [343.541:004]:159

\section{ЕЛЕКТРОННІ ОСВІТНІ РЕСУРСИ ЯК ЗАСІБ ФОРМУВАННЯ ЦИФРОВОЇ КОМПЕТЕНТНОСТІ МОЛОДШИХ ШКОЛЯРІВ У ПРОЦЕСІ ОНЛАЙН ТА ОФЛАЙН НАВЧАННЯ}

\footnotetext{
Анотація. Сьогодні світ перебуває у процесі швидкої інформатизації та діджиталізації суспільства у всіх його сферах. Спосіб і темп життя сучасної людини не схожий на життя попередніх поколінь. Поширення хвороби коронавірусу COVID-19 зумовило необхідність прийняття та адаптації до нових умов праці та навчання для освітян із різних країн. Навчальні заклади у всьому світі реагують на численні обмеження та правила карантину 3 переходом на дистанційне навчання. Криза вже спричинила бум на дистанційну освіту і змусила педагогів бути готовими до вирішення цієї нетипової ситуації. Найпотужніше джерело інформації сьогодні - цифрові технології, або як їх ще називають - цифрові засоби навчання, що передбачають компетентне використання найновіших гаджетів. Звичайно, глобальні зміни у суспільному житті не можуть відбуватися без змін в освітньому просторі, тому наша система освіти упевнено слідує за досвідом передових європейських країн та впроваджує багато програм із метою формування та розвитку цифрової компетентності особистості, починаючи з початкової ланки освіти.

Безумовно, українська освіта, що переймається досвідом Нової української школи, передбачає широке використання інформаційно-комунікаційних технологій кожним педагогом у власній професійній педагогічній діяльності, що є важливим способом оновлення та інформатизації змісту освіти в різних навчальних закладах країни. Цей процес неможливий без систематичного використання електронних освітніх ресурсів під час навчання, оскільки вони створюють модернізований зміст навчального простору, забезпечують рівний доступ до освітніх онлайн-
} 
матеріалів для кожного учасника навчального процесу незалежно від місцезнаходження, віку чи інших аспектів і сприяють формуванню цифрової компетентності учнів.

Ключові слова: електронні освітні ресурси, формування цифрової компетентності, молодші школярі, Нова українська школа, вчителі початкових класів.

\title{
ELECTRONIC EDUCATIONAL RESOURCES AS A MEANS OF FORMATION OF DIGITAL COMPETENCE OF PRIMARY SCHOOL STUDENTS IN THE PROCESS OF ONLINE AND OFFLINE EDUCATION
}

\begin{abstract}
Today the world is in the process of rapid informatization and digitalization of society in all its spheres. The way and pace of life of a modern man is not similar to the life of previous generations. The spread of the coronavirus disease, known as COVID-19, has necessitated acceptance and adaptation to new working and learning conditions for educators from different countries. Educational institutions around the world are responding to numerous prohibitions and quarantine rules with the transition to distance learning. The crisis has already caused an online boom for education and forced teachers to be prepared to deal with this atypical situation. The most powerful source today is digital technology, or as they call it - digital learning tools, which implies competent use of the latest gadgets. Of course, global changes in public life cannot take place without changes in the educational space, so our education system now follows the experience of advanced European countries and implements many programs for the formation and development of digital literacy, including at the educational level.

Definitely, Ukrainian education system follows the experience of advanced New Ukrainian School provides for the widespread use of information and communication technologies by each teacher in their own professional and pedagogical activities, which is an essential way to update and informatize the education content in different education institutions of our country. This process is impossible without the systematic use of electronic educational resources (EER) during the educational process, because they definitely create a modernized content of educational space and provide equal access to educational online materials to each participant in the educational process regardless of location, age or other aspects.

Keywords: electronic educational resources, digital competence formation, primary school students, New Ukrainian School, primary school teachers.
\end{abstract}

\section{INTRODUCTION}

Problem setting. Extensive study and analysis of the state of informatization and computerization of education has shown us that today active teachers-practitioners, who "keep up" with time and reforming education, regularly use electronic educational resources to form digital competence of primary school students and implement new forms of learning: mixed, electronic, mobile or network (Blyznyuk T., Slyusarchuk T., 2019).

According to the Concept of New Ukrainian School, a graduate of a general secondary education institution must be competent in the digital field, be able to operate with information, think critically and carry out innovative activities. Thus, it became clear that to form such a personality who possesses a digital competence is possible only by training a competent teacher and creating a modern innovative information and digital learning environment. Therefore, the popularity of the use of e-learning resources (EER) in the educational process of Ukrainian schools is due to these factors. Besides, "alongside with remarkable attention of European Commission to the development of digital competence for teachers Ukrainian governmental officials simultaneously stress on teachers' readiness for innovation, new standards and learning outcomes, and emphasize the importance of forming key competences in schoolchildren for lifelong learning. Among ten major competences of the Ukrainian school are the following: communication in national and foreign languages, competencies in Science and Technology, ICT and digital competences, etc" (Blyznyuk T. 2018. p. 43). According to the document, "these key competencies and cross-disciplinary abilities create an infrastructure that provides the grounds for successful self-fulfillment of the pupil as a personality, citizen and professional" (New School - Ministry of Education and Science of Ukraine. 2016. p. 12).

Analysis of research and publications. Creative educators always try to keep up with the latest developments in innovative technologies; however, in our time, humanity needs new knowledge and new ideas to adapt to the current situation on the planet. It requires scientists and researchers to find and create new approaches and solutions for many sectors in order to survive and move forward. Even those with primary education as part of the existing economic system are also forced to meet the challenge. Many centuries ago, Plato proclaimed that "necessity is the mother of innovation", and we clearly feel that need today.

However, the introduction of electronic educational resourcesin the education practice is still slow and mostly chaotic, which negatively affects the quality of the process itself and its results. Recent studies in this direction (Morse N., Bykov V., Gurevych R., Kademia M., Kozyar M., Spirin O., Pinchuk O., Raitska L., Proshkin V., Tkachuk G., Shyshkina M., Popelta M., etc.) reveal general theoretical principles of the use of information and communication technologies, web technologies, cloud and remote technologies, educational electronic resources, etc. in teaching process. However, these studies mostly provide partial lists and descriptions of EER, often focusing only on certain areas of their application.

Apart from big interest from the researchers part to the problem of digitalization of education, numerous requirements for the introduction of which are specified in many government regulations: "On conducting a pedagogical experiment on teaching future teachers and teachers of information and communication technologies", "Concept of scientific, technical and innovative policy in the system of higher education of Ukraine", "On the functioning of the Internet portal "Unified educational information window of Ukraine", "On measures to implement e-learning content", "Regulations on electronic 
educational resources", "On creating an information-educational environment based on open electronic resources "Shchodennyk.ua", "On the systematization of the experience of using electronic educational resources", etc.

Purpose and objectives of the research. The purpose of the article is to introduce the classification of open educational electronic resources, suggest their use in online and offline education, as well as substantiate some aspects of the methodology of their use for formation of digital competence of primary school students.

Research results. We are faced with the need to carry out a terminological analysis of the concept of "electronic educational resource". Having analyzed the materials of the domestic and foreign scientific papers, we attempt to say that domestic source base does not provide sufficient definitions of the term "electronic educational resource", however, we will offer several the mist appropriate in our opinion definitions of this notion.

Open education electronic resources are extremely popular in the USA and Europe and offer a wide experience of their use (Heather Seibert, Rachel Miles \& Christina Geuther, 2019) in their study they mentioned that open EER "are teaching and learning materials that you may freely use and reuse at no cost, and without needing to ask permission ... Open EER have been authored or created by an individual or organization that chooses to retain few, if any, ownership rights. Therefore, they must follow the Five Rs of use: Retain, Reuse, Revise, Remix, and Redistribute. EER are present in diverse formats including audio, visual, animation, and print. They include different types of materials, such as tests, textbooks, curriculum, syllabi, lecture notes, photographs, projects, and more. There are numerous places where open EERs can be found, many of which are used every day by instructors, librarians, teachers, and researchers. Examples of open EER platforms and websites include C-K12, OpenStax, Pixabay, Flickr, Khan Academy, Curriki, and MIT OpenCourseware" and many others (Heather Seibert, Rachel Miles \& Christina Geuther, 2019).

A basic Guide to open educational resources prepared by Neil Butcher for the Commonwealth of Learning \&UNESCO $(2011,2015)$ provides readers with a quick and user-friendly introduction to OEER and some of the key issues to think about when exploring how to use them most effectively. The author explains that in its simplest form, the concept of Open Educational Resources (OER) describes any educational resources (including curriculum maps, course materials, textbooks, streaming videos, multimedia applications, podcasts, and any other materials that have been designed for use in teaching and learning) that are openly available for use by educators and students, without an accompanying need to pay royalties or licence fees.

Similar explanation is suggested by another researcher (Atkins D. (2007), p. 4) as: "teaching, learning, and research resources that reside in the public domain or have been released under an intellectual property license that permits their free use or re-purposing by others." Under this definition, EER includes several types of educational resources such as course materials, modules, books, videos, tests, software, or even techniques used to support access to knowledge. It is important to note that this perspective on OER puts special focus on digital ecologies, which enables access and sharing of licensing content, mainly via the Internet (Littlejohn Allison, Hood Nina , 2017).

Thus, having explored the essence of the concept of "electronic educational resources", we understand that they are one of the main elements of the information and digital space and allow to expand the boundaries of information by using many sources that are not always possible to find in libraries.

Examining the problem of "electronic educational resources" in studies conducted by domestic researches, we understood that scientists were actively researching them and single out the following for their broader functional classification (See Fig. 1):

\begin{tabular}{|c|c|}
\hline $\begin{array}{l}\text { Program-methodical } \\
\text { •curricula } \\
\text { • academic discipline programs }\end{array}$ & \\
\hline $\begin{array}{l}\text { Educational and methodical } \\
\text {-methodical instructions and recommendations for te }\end{array}$ & c disciplines \\
\hline $\begin{array}{l}\text { Educational and didactic } \\
\text { •textbooks } \\
\text { - manuals }\end{array}$ & \\
\hline $\begin{array}{l}\text { Intermediate } \\
\cdot \text { collections of tasks and exercises } \\
\cdot \text { directories } \\
\cdot \text { e-books } \\
\cdot \text { tools }\end{array}$ & \\
\hline $\begin{array}{l}\text { Evaluative } \\
\text { •tests programs } \\
\text { •platforms foe formative and summative assessment }\end{array}$ & \\
\hline
\end{tabular}

Figure 1. Classification of EER by their functionality 
After examining Fig. 1, we can say that all open EERs in general function to improve the efficiency of the educational process and can be widely used in the process of forming digital competence of students of different age groups. However, most educators focus on the process of university students' independent work in order to train the future teachers, for teachers self-education; organization of practical work in the university classroom; for the organization of extracurricular work on the academic discipline (Gurevych R., Kademiya M., Kozyar M., 2012, p. 57 - 58). Scientists preferably disclose methods of using EER in the process of training future teachers of computer science (Tkachuk G.V., 2011); formation of a cloud-oriented learning environment for mathematical disciplines (Shyshkina M.P. 2016) and more. Alas, we could not find many works dealing with the training of future primary school teachers for the use of EER in New Ukrainian school or formation primary schoolchildren's digital competence by means of EER.

Using multimedia electronic educational resources, the primary school teacher will enrich the lesson with interesting and non-standard forms and methods of interaction with students, provide space for students' creative independent work and educational base for digital competence formation, alongside with the possibility of their own research activities.

We can admit that using EER as one of the means and tools for the formation of digital competence of primary school students also changes the way of interaction and communication between the participants in the educational process, which is necessary for the current generation of students who are accustomed to communicate and interact with each other through gadgets. However, "using active learning with all innovative instruments of learning/teaching does not necessarily mean complete ignoring the traditional format, but it does take class time. Teachers who use active learning methods make frequent pauses during the period in order to give students some time to work out the information they are provided with. Teachers may ask students to respond to several questions, to summarize important concepts orally or in writing, or compare notes with a partner. Breaking students into groups or other strategies such as individual writing or paired activities are quite possible and lead to good results as well. There are many teaching strategies that can be successfully used to actively engage students in the learning process and develop their competences, including group discussions, problem solving, case studies, role plays, journal writing, and structured learning groups, etc. There are many benefits to using such activities, as they aim to improve critical thinking skills, increase retention and transfer new information, increase motivation, and improve interpersonal skills and other competences. Students and their learning needs must be at the center of active learning both at schools and higher educational institutions. And perhaps we should give less attention to those tests we got used to, but evaluate students or teachers according three $\mathrm{C}$ approach: communication, creativity, critical thinking and collaboration?" (Blyznyuk T., 2018, p. 40-45).

Exploring the EER of fast and simultaneous interaction of students and teachers in the classroom, we drew attention to the popular among the pedagogical community application for browsers Pear Deck. With its help, the teacher has the opportunity to simultaneously display on all students' smartphones prepared in advance photos, presentations and videos. Another essential advantage is the possible synchronization with the Google Drive, for example, the teacher uses one's own saved materials (photos, audio, video, presentations, etc.) and instantly places them in the Pear Deck. The teacher provides access to virtual lessons through the code that students enter on their own devices, where they have the opportunity to process learning materials. The students do not need to raise the hand, as to answer, they are interviewed and tested on computers or phones. Conducting an anonymous discussion about what is seen or read in digital online form makes it impossible for other students to condemn the students' opinions, because the person who responded is reflected only to the teacher, so each child expresses oneself without fear of making mistakes or being condemned by classmates. It is necessary to note that with this resource, students can complete the teacher's tasks, supplementing the presentation with their content immediately during the lesson. For example, a teacher may ask students to write an essay based on a poem they study in classroom.

For the teacher, the value of this EER is in mobility, getting instant feedback, conducting a quick survey, displaying the results individually. Using Pear Deck helps to manage time efficiently and perform quality formative assessment, which makes it impossible for a teacher to make a mistake when checking the answers. Another important factor is the function of analyzing all the answers of students in general and each of them, which will be reflected in the schedule, so the teacher can immediately track the students' academic achievements, and know what teaching material needs closer attention.

Kahoot proved to be another interesting and interactive resource, which integrates a game and testing. This EER is suitable for studying any subject at any education institution. It can be used for conducting testing and independent work, quick surveys, individual and group discussions, for traditional or formative assessment and reflection. Starting with this resource, the teacher sees that the system offers several types of Kahoot! We can use it to create quizzes, surveys and tests. The teacher has the perfect opportunity to monitor and analyze student responses and general progress, because the results are automatically saved and can be displayed in the MS Excel editor. This EER gives the educator exclusive opportunity to analyze students' mistakes or difficulties in answering the questions thoroughly. For example, the teacher can see which questions proved to be complicated and took much time to answer.

Another huge advantage of this open EER for teachers is that the service has a selection of ready-made tests in numerous subjects and their topics that can be used by those who are registered for free in their own lessons.

However, everyone knows that in reality, many schools are practically not equipped with sets of technical means, and not always every student has a smartphone or carries it to school. In such a situation electronic resource Kahoot! provides a solution to this problem and offers the teacher a strategy for interaction with the whole class, when only the teacher has a laptop, phone or tablet.

Thus, we can conclude that systematic use of Kahoot! in the educational process is not only a valuable means of feedback, but also a perfect tool for formative assessment. Therefore, the teacher does not only assessments and tests 
the knowledge acquired by the student, but also prevents the development of fear of error and, accordingly, promotes student's confidence, celebrates any success of the student and focuses only on strengths, not on mistakes and failures, encourages students to achieve goals and the highest learning outcomes.

In the context of formation students' digital competence, the electronic educational resource Kahoot! helps to develop skills of rapid mastery of technology, the junior student learns to analyze and critically evaluate information or digital content, as well as develops the ability to interact in the digital environment with the help of modern technologies.

Our attention was also drawn to the electronic educational resource Mentimeter, another service with a wide range of educational opportunities. It just like Pear Deck and Kahoot! helps to interact with all the participants in the educational process. Mentimeter is a resource which you can quickly survey the whole class with and show students the results. As in Pear Deck and Kahoot! the teacher creates questions and displays them on the screen. The application automatically generates a task code - you need to voice it to students, give a link with an access code or provide a QR code for scanning. Teachers who actively implement Mentimeter in the educational process of general secondary education institutions advise to use it to understand which topic most students have dealt with the worst or, conversely, which is of great interest, for example, to invite students to participate in the creation and lesson planning and choose what they want to discuss at the lesson. Therefore, you can immediately focus on what to look for.

A positive feature of this resource, which differentiates it from Pear Deck and Kahoot!, is the ability to create a word cloud at the lesson. In addition, the teacher can arrange weekly final surveys in which students will vote for the best or most interesting lesson, task, topic or, for example, the literary hero of the week, getting the results in percentage, graph, chart or a "word cloud".

The resource, preserving all the results of each survey provides an opportunity to track the level and dynamics of learning material throughout the class. Practitioners argue that these features are sufficient to make full use of the Mentimeter for various purposes. They also believe that the big advantage is that you do not need to download additional software to your computer, laptop, tablet or mobile phone.

Deeply studying the problem of introducing electronic educational resources in primary school, which help to establish the relationship between participants in the educational process, we understand that many such resources provide the ability to use services and programs to create QR-codes and work with them to ensure instant interaction and class, which saves teacher's time greatly. Here is an example of such an invaluable assistance for teachers as the service QR Code Generator. According to users, it is a scanner and a generator of QR-codes. Actually, QR-Code is a type of bar code that is read using a phone or tablet camera. The code consists of black modules that are arranged in a square pattern on a white background. The encoded information can be the text you want to read to students, a photo, a website, a web resource, an application, a video, or even a simple lesson plan and much more. The student only needs to open the site of the QR Code Generator service, point the smartphone camera at the code, and the program itself redirects the student to the desired material. This service can be used to quickly disseminate information and to diversify the learning process, for example, when creating and passing a web-quest, to create collections of materials and easy access for students to them. With a QR-code, the student saves time because there is no need to type a link and one has no chance to enter the wrong web address.

From our experience of distance learning during spring semester of 2020, these and many other open EER proved to be an integral part of the educational process and showed their efficiency for arranging tests, independent work, quick surveys, private and group discussions, instant feedback, formative and summative assessment and reflection.

Having finished the semester, we organized a survey of 40 students of the Pedagogy Faculty, future primary school teachers, who passed the academic disciplines "Methods of teaching English in primary school", "Practical course of English", "English Literature for children" and others. Among numerous questions offered to students we wanted to get to know if they find distance learning with the use of various EER efficient for getting necessary knowledge, skills, abilities and competences (See Diagram 1).

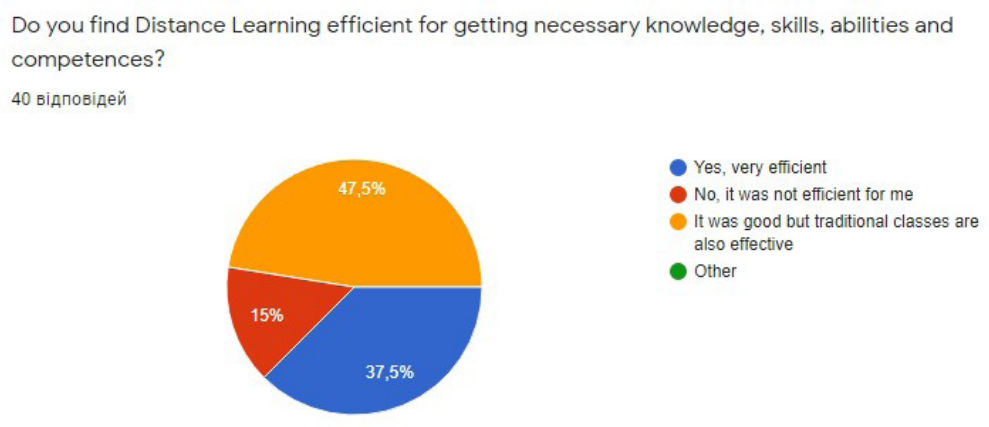

Diagram 1. Pedagogy students' attitude to the efficiency of distance learning and the use of EER

Having analyzed Diagram 1, we became aware of the fact that 19 out of 40 respondents ( $47,5 \%)$ consider distance learning good but traditional also effective. 15 students (37,5\%) find distance learning very efficient and only 6 participants of our survey (15\%) saw no efficiency in it. We might assume the reasons for those $15 \%$ of the respondents who did not experience any use of EER online in difficulties they had during the teaching/learning process See Diagram 2). 
Most of them dealt with some technical problems - 31 students $(77,5 \%)$ and poor WI-FI connection - 25 (62,5\%).

Having studied and analyzed the possibilities of using EER in primary school practice, we must say that the use of e-learning resources as an element of learning has its advantages and disadvantages. The EER we reviewed earlier, namely Pear Deck, Kahoot!, Mentimeter, QR Code Scanner and Generator, reduce the cost of producing and distributing learning materials, provide easy and quick access and immediate feedback during lessons.

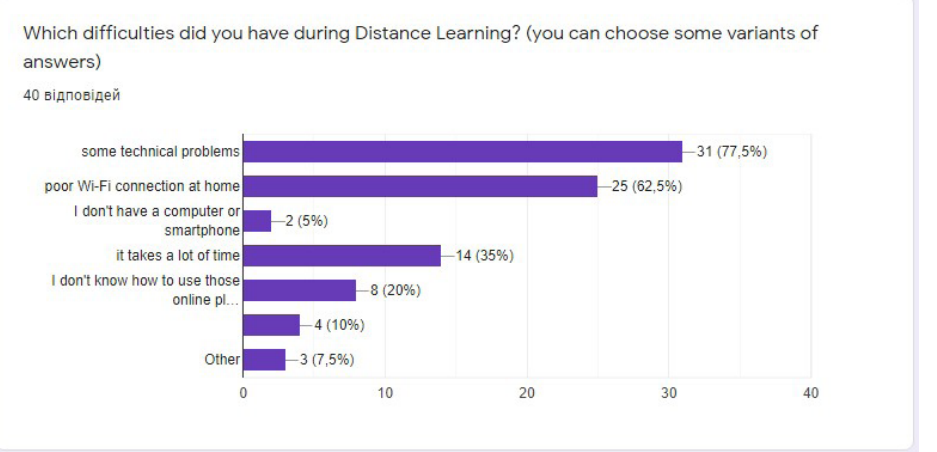

Diagram 2. Difficulties students had during distance learning and the use of EER

The use of means of quick interaction between teacher and students in the classroom today is necessary, because this process makes the student's independent work more intense, saves time, and facilitates the process of assessment and analysis of knowledge acquisition.

The whole process of working with these resources is accompanied by the formation of a digital competence and digital culture of junior high school students; the anonymity of answers during discussions, testing, surveys or quiz in front of classmates increases confidence and reduces stress. However, their use requires an appropriate technological infrastructure, which may be inaccessible sometimes (computer, smartphone, Internet connection, etc), especially in small rural schools, which there are many in Ukraine.

\section{CONCLUSIONS AND PROSPECTS OF FURTHER RESEARCH}

From the above we can conclude that the level of modern education must meet the requirements of the society, because the level of potential of Ukraine in all its spheres depends on the extent to which the current generation of students will develop digital competence. Today, the introduction of digital technologies in the daily life of the society is inevitable, and therefore, has become one of the priorities of public policy, including education sector.

At present, we can see how Ukraine is confidently moving in reforming the education system within the New Ukrainian School, which is based on the introduction of new approaches to teaching and educating students, creating a modern and relevant educational space, combining traditional and innovative learning, implementing in the educational process of radically new means of teaching and education. These tools are based on the use of information and communication technologies and provide for the inevitable formation of competencies of the personality of the junior student, among which one of the priorities is the digital competence of the student of primary school and later school leaver. The latest technologies globally affect the forms, approaches, methods and means of teaching, but their rapid development requires the simultaneous development of methods of their application in the educational process of general secondary education, including primary school. Today there is a great contradiction between the wide range of possibilities of open EER and the ways of their introduction in online and offline education.

Nowadays, the problem of using gadgets and various technical devices in the educational process is extremely relevant, and its study is crucial and demands deeper analysis. Definitely, it is impossible to consider the problem of digitalization and modernization of education without changing the activities of the teacher, because the presentation of factual material is not enough today, the teacher from the "giver" of knowledge changes to a facilitator, mentor or tutor, who shows how to get certain information. To achieve this goal, first of all, the education system needs to modernize the methods of teaching in primary education by modern EER and provide teacher training at the state level, and not rely only on self-education of active educators.

\section{REFERENCES}

Atkins, D. E. (2007). A review of the open educational resources (OER) movement: achievements, challenges, and new opportunities. Menlo Park: The William and Flora Hewlett Foundation.

Blyznyuk T. (2018). Formation of teachers' digital competence: domestic challenges and foreign experience. Journal of Vasyl Stefanyk Precarpathian National University. Scientific edition. Series of Social and Human Sciences.

Blyznyuk T., Slyusarchuk T. (2019). Formation of digital competence of primary school children. Ivano-Frankivsk.

Gurevych R. S., Kademiia M. Yu. \& Koziar M. M. (2012). Informatsiino-komunikatsiini tekhnolohii v profesiinii osviti. Lviv: Spolom.

Littlejohn Allison, Hood Nina. (2017). How educators build knowledge and expand their practice: The case of open education resources. British journal of educational technology. https://doi.org/10.1111/bjet.12438

New School - Ministry of Education and Science of Ukraine. - Available at: mon.gov.ua/Новини\%202016/08/21/2016-08-17-3

Proshkin V. (2017). Osvitni veb-resursy v profesijni pidgitivtsi maibutnikh uchytrliv. Osvitologichnyi dyskurs. ISSN Online: $2312-5829$ 


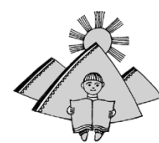

Seibert Heather, Miles Rachel, \& Geuther Christina. (2019). Navigating 21st-Century Digital Scholarship: Open Educational Resources (OERs), Creative Commons, Copyright, and Library Vendor Licenses, The Serials Librarian., 76:1-4, P. 103-109, DOI: 10.1080/0361526X.2019.1589893

Shyshkina M. (2016). Formuvannia khmaroorientovanogo seredovyshcha navchannia matematychnykh dystsyplin na bazi SAGEMATHCLOUD. Informatsijni tekhnologii v osviti.Available at: http:/lite.kspu.edu/home DOI: 10.14308/ite000578

Tkachuk G. (2011). Metodyka vykorystannia osvitnikh veb-resursiv u protsesi pidgotovky maibutnikh uchyteliv informatyky. Monigrafia. Uman. "Sochinskyi".

UNESCO and Commonwealth of Learning. A basic Guide to open educational resources $(2011,2015)$. Available at: https://cutt.ly/pyXY8X
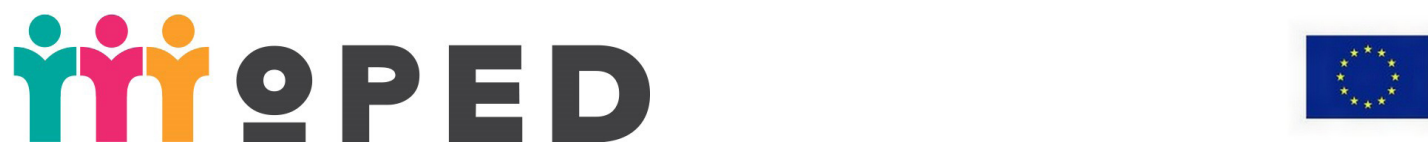

«The article has been prepared in the framework of the Erasmus+ project "MoPED - Modernization of Pedagogical Higher Education by Innovative Teaching Instruments", No. 586098-EPP-1-2017-1-UA-EPPKA2-CBHE-JP. This project has been funded with support from the European Commission. This publication reflects the views only of the author, and the Commission cannot be held responsible for any use which may be made of the information contained therein» 